\title{
STUDIES AND ANALYSIS OF REFERENCE MANAGEMENT SOFTWARE: A LITERATURE REVIEW
}

\author{
Estudios y análisis de software para gestión de \\ referencias: revisión bibliográfica
}

\author{
Jesús Tramullas, Ana I. Sánchez-Casabón and Piedad Garrido-Picazo
}

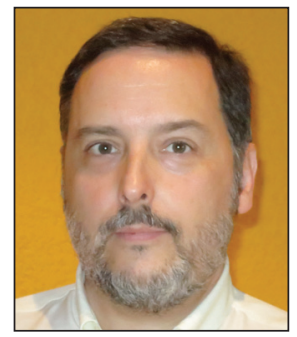

Jesús Tramullas, PhD in philosophy (history) and master in computer management (IDE / Cesem), is an associate professor at the Department of Library \& Information Science, Univ. of Zaragoza, Spain. He has directed and developed several funded research projects on information management in organizations. Academic coordinator of master and doctorate studies (2004-2012). Senior member of the Association for Computer Machinery (ACM) and International Society for Knowledge Organization (ISKO). Member of Drupal Association and Wikimedia ES. His research interests relate to software tools' evaluation, content management, information behavior, and Wikipedia. http://orcid.org/0000-0002-5374-9993

Universidad de Zaragoza, Departamento de Ciencias de la Documentación Pedro Cerbuna, 12. 50009 Zaragoza, Spain tramullas@unizar.es

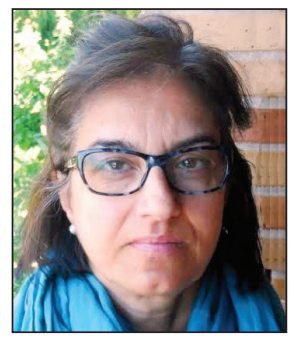

Ana I. Sánchez-Casabón, PhD in philosophy (history), is an associate professor at the Department of Library \& Information Science, University of Zaragoza, Spain. She has participated in several funded research projects investigating document management and information literacy. She is a member of the Intelligent Networks and Information Technologies Research Group. Her current research interests include user studies, information literacy, and educational aspects of information. http://orcid.org/0000-0002-0908-1615

Universidad de Zaragoza, Departamento de Ciencias de la Documentación Pedro Cerbuna, 12. 50009 Zaragoza, Spain asanchez@unizar.es

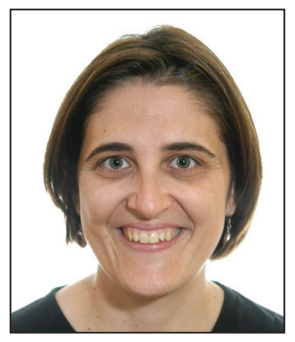

Piedad Garrido-Picazo is an assistant professor in the Department of Computers and Systems Engineering, University of Zaragoza, Spain. She graduated in computer science in 1997 and documentation in 1999 at the Universitat Politècnica de València. She received her PhD degree in documentation from the University Carlos III of Madrid in 2008. Her current research interests include information management and metadata, intelligent transportation systems, virtual agents, traffic safety, and vehicle and infrastructure communications. She is member of the IEEE.

http://orcid.org/0000-0002-1750-7225

Universidad de Zaragoza, Departamento de Informática e Ingeniería de Sistemas Ciudad Escolar, s/n. 44003 Teruel, Spain piedad@unizar.es

\begin{abstract}
Reference management software is a well-known tool for scientific research work. Since the 1980s, it has been the subject of reviews and evaluations in library and information science literature. This paper presents a systematic review of published studies that evaluate reference management software with a comparative approach. The objective is to identify the types, models, and evaluation criteria that authors have adopted, in order to determine whether the methods used provide adequate methodological rigor and useful contributions to the field of study.
\end{abstract}

\section{Keywords}

Reference management software; Reference managers; Citation managers; Bibliography database managers; Bibliographic software; Citation management tools; Evaluation methods; Bibliography; Review. 


\section{Resumen}

Los gestores de referencias son una herramienta clásica para el trabajo de investigación científica. Desde la década de 1980 han sido objeto de revisiones y evaluaciones en la bibliografía especializada. Este trabajo plantea una revisión sistemática de los trabajos publicados que evalúan gestores de referencias con un enfoque comparativo. El objetivo del mismo es identificar los tipos, modelos y criterios de evaluación que han adoptado los autores, para determinar si los métodos utilizados ofrecen el rigor metodológico adecuado, y si suponen una aportación al conocimiento sobre el tema objeto de estudio.

\section{Palabras clave}

Gestores de referencias bibliográficas; Gestores de citas; Software bibliográfico; Bibliografía; Métodos de evaluación; Revisión.

Tramullas, Jesús; Sánchez-Casabón, Ana I.; Garrido-Picazo, Piedad (2015). "Studies and analysis of reference management software: a literature review". El profesional de la información, v. 24, n. 5, pp. 680-688.

http://dx.doi.org/10.3145/epi.2015.sep.17

\section{Introduction and background}

Reference management software has been a useful tool for researchers since the 1980s. In those early years, tools were made ad-hoc, and some were based on the dBase II/III database management system (Bertrand; Bader, 1980; Kunin, 1985). In a short period of time a market was created and commercial products were developed to provide support to this type of information resources. The need of researchers to systematize scientific literature in both group and personal contexts, and to integrate mechanisms into scientific production environments in order to facilitate and expedite the process of writing and publishing research results, requires that these types of applications receive almost constant attention in specialized library and information science literature.

\section{The need of researchers to systematize scientific literature requires that referen- ce management software receives almost constant attention in specialized library and information science literature}

The result of this interest is reflected, in bibliographical terms, in the publication of numerous articles almost exclusively devoted to describing, analyzing, and comparing the characteristics of several reference management software products (Norman, 2010). Using these studies it is possible to trace use and consumption patterns in scientific information along with production and publication processes. The review and study of the contents of these articles, over an extended period of time, can provide data on the evolution of user needs, industrial life cycles, and the development of evaluation processes of software tools geared toward scientific information management.

A significant number of publications have focused on providing researchers and professionals with the information needed to decide which tool is best to meet their needs. To that end, several authors have provided individual or overall assessments of the tools available, in accordance with various criteria and approaches. Although Moore (1991) originally suggested an evaluation grid for highlighting features in reference management software, it is only recently that some basic proposals have been published in order to develop specifically designed evaluations for these tools (Marino, 2012).

\section{Goals and working hypotheses}

As mentioned earlier, the main goal of this article is to identify and analyze the guidelines, processes, and evaluation techniques used in articles when evaluating reference management software. A secondary goal of this article is to identify the scientific area of publication where the various articles reviewing reference management software are located. Lastly, this research will provide an overview of the temporal evolution of functions provided by reference management software tools.

The working hypothesis for this article is that published assessments of reference management software are not based on rigorous methodological analysis, which ultimately degrades the quality of the publications and the value such articles might have for their intended audiences.

\section{Methodology}

The method adopted for this article follows the traditional approach of a systematic literature review. To that end, the eight steps formulated and suggested by Okoli and Schabram (2010) for systematic literature reviews of information systems were followed. The research goals were defined and the information and required data were collected and subsequently tabulated, ordered, reviewed, and analyzed. This process allows articles to be characterized in accordance with several domains. Finally, the findings were compared with the established working hypothesis.

\section{Data collection}

A literature search of the databases Web of Science and Scopus was conducted in March 20, 2015, using the search expressions TITLE-ABS-KEY("citation management software") OR TITLE-ABS-KEY("reference management software") OR TITLE-ABS-KEY("citation tools") OR TITLE-ABS-KEY("citation reference"). Web of Science produced 58 results, 32 of which were selected. Scopus produced 130 results, the 
Table 1. Reference management software revised papers

\begin{tabular}{|c|c|c|c|c|}
\hline Author(s) & Year & Journal & Knowledge area & Type of review \\
\hline Gurney; Wigton & 1987 & American journal of roentgenology & Biomedicine & Description \\
\hline Brantz; Galla & 1988 & Bull Med Libr Assoc & Biomedicine & Comparative description \\
\hline Garfield; Flanagan; Fox & 1989 & Journal of clinical monitoring and computing & Biomedicine & Quantitative comparison \\
\hline Nashelsky; Earley & 1991 & Library software review & Library \& inform. science & Description \\
\hline Jones & 1993 & BMJ & Biomedicine & Description \\
\hline Miller & 1994 & MD Computing: computers in medical practice & Biomedicine & Comparative description \\
\hline Cibbarelli & 1995 & Computers in libraries & Library \& inform. science & Comparative description \\
\hline Tramullas & 1995 & Tendencias de investigación en documentación & Library \& inform. science & Comparative description \\
\hline Nicoll et al. & 1996 & Computers in nursing & Biomedicine & Comparative description \\
\hline Bravo-Toledo & 1996 & El profesional de la información & Library \& inform. science & Description \\
\hline Bravo-Toledo; Astorga-Díaz & 2000 & Atención primaria & Biomedicine & Description \\
\hline Shapland & 2000 & Library and information briefings & Library \& inform. science & Comparative description \\
\hline Koopman & 2002 & Internet reference services quarterly & Library \& inform. science & Comparative description \\
\hline May & 2003 & The scientist & Multidisciplinar & Description \\
\hline Kessler; Van Ullen & 2005 & The journal of academic librarianship & Library \& inform. science & Quantitative comparison \\
\hline Mattison & 2005 & Searcher & Library \& inform. science & Comparative description \\
\hline Duarte-García & 2007 & El profesional de la información & Library \& inform. science & Comparative description \\
\hline Smith; Baker & 2007 & International journal of mental health nursing & Biomedicine & Comparative description \\
\hline Giménez; Tramullas & 2007 & IX Jornadas españolas de documentación & Library \& inform. science & Comparative description \\
\hline Hernández; El-Masri; Hernández & 2008 & Diabetes educator & Biomedicine & Comparative description \\
\hline Gomis; Gall; Brahmi & 2008 & Medical reference services quarterly & Biomedicine & Comparative description \\
\hline Cordón-García et al. & 2009 & El profesional de la información & Library \& inform. science & Comparative description \\
\hline Butros; Taylor & 2010 & $36^{\text {th }}$ lamslic annual conference & Library \& inform. science & Description \\
\hline Fenner & 2010 & Cellular therapy and transplantation & Biomedicine & Description \\
\hline Alonso-Arévalo & 2010 & Anuario ThinkEPI & Library \& inform. science & Description \\
\hline Gilmour; Cobus-Kuo & 2011 & Issues in science and technology librarianship & Library \& inform. science & Comparative description \\
\hline Kern; Hensley & 2011 & Reference \& user services quarterly & Library \& inform. science & Description \\
\hline Rapp & 2011 & Library journal & Library \& inform. science & Description \\
\hline Web; Platter & 2011 & Ukolug newsletter & Library \& inform. science & Comparative description \\
\hline Glassman; Sorensen & 2012 & Journal of electronic resources in medical libraries & Biomedicine & Comparative description \\
\hline Zhang & 2012 & Medical reference services quarterly & Biomedicine & Comparative description \\
\hline Mahajan; Hogarth & 2013 & Chest & Biomedicine & Comparative description \\
\hline Steeleworthy; Dewan & 2013 & $\begin{array}{l}\text { Partnertship: the Canadian journal of library and } \\
\text { information practice and research }\end{array}$ & Library \& inform. science & Comparative description \\
\hline Homol & 2014 & The journal of academic librarianship & Library \& inform. science & Comparative description \\
\hline Casado-Pardo et al. & 2014 & $\begin{array}{l}\text { FMC - Formación médica continuada en atención } \\
\text { primaria }\end{array}$ & Biomedicine & Description \\
\hline Yamakawa et al. & 2014 & Transinformação & Engineering & Description \\
\hline Basak & 2014 & Journal of economics \& behavioral studies & Engineering & Quantitative comparison \\
\hline
\end{tabular}

subsequent review of which narrowed down the selection to 55. Once the core of articles suitable for evaluation was identified, the process was extended to identify other publications through Google Scholar and Dialnet. The search for references was completed using the bibliographies of suitable articles, by searching specialized interest groups in Mendeley and Zotero, creating a final list of 100 possible articles. http://webofknowledge.com

http://scopus.com

https://scholar.google.com

http://dialnet.unirioja.es

https://mendeley.com

https://zotero.org

Once the references were organized and refined, a systematic review process was followed in order to identify those articles fitting the parameters of this study. To that end, the selected articles were those providing a review or description of two or more reference management software tools.
Articles that focused on news, tutorials, or specific tool descriptions were rejected. The process identified 37 articles that provided a description or comparison between two or more reference management software tools. For each particular article, information regarding authorship, year; journal; conference proceedings; area of knowledge of the journal; and type and evaluation characteristics was provided.

\section{Results analysis and discussion}

The 37 articles reviewed (table 1) were published between 1987 and 2014. There is not a particular year in which more studies were published, although publication frequency increased for a decade beginning in 2000. Four studies were identified between 2011 and 2014.

From the 37 texts reviewed, only three of them were published in conference proceedings. The rest were published in specialized journals: none of them are more significant with regard to the amount of articles published. There is only one 
exception, El profesional de la información (EPI), a journal that published four of the articles reviewed; in addition, a fifth article was published in its related publication Anuario ThinkEPI. Regarding the language in which they were written, nine articles were in Spanish and published between 1995 and 2014.

Each journal and article was assigned to an area of knowledge. Applying the most accepted division, the areas of knowledge used were Biomedicine, Social sciences and law, Engineering and computer science, and Humanities. In addition, the specific area of Library and information science was created. Data show that most of the articles focus on the areas of Biomedicine (15 articles, 40.5\%) and Library and information science (19 articles, 51.4\%), which amount to $91.9 \%$ of all the articles. If the series is reviewed chronologically, there were slightly more articles published in the area of Library and information science from 1995 onward. The high percentage of publications in Biomedicine and Library and information science indicates a particular concern or interest in both communities regarding the state, evolution, and use of software management tools.

Most of the articles focus on the areas of Biomedicine (15 articles, 40.5\%) and Library and information science (19 articles, $51.4 \%)$

The evaluations conducted by the authors of the 37 articles are the main object of analysis and discussion in this article. Two levels of review were used to study the articles:

1. The first level corresponds to the type of review conducted by the authors of each study. Three types were identified:

- Description: articles where authors described various aspects of the software management tools, but did not include a systematic comparison of values.

- Comparative description: articles where authors included a systematic comparison between software management tools by assigning values of some kind in the comparison.

- Quantitative comparison: articles where authors included a systematic comparison by assigning numerical values to individual parameters in order to obtain assessments within a pre-established scale.

2. The second level corresponds to the functions or items that the authors used as indicators in the study. This level focused on considering which specific functions were used in each of the overall studies, and under which parameters.

Most of the articles $(19,51.4 \%)$ chose a comparative description approach to analysis. There is not a significant difference between the areas of Library and information science and Biomedicine (10 articles in the first case, 9 in the second). However, the concept of comparative description, or how it is approached in the publication, varies among the analyzed articles. Several authors conducted a comparative study with a narrative structure, either when describing each software tool or when describing a function or characteristic. A few articles focused exclusively on contrasting specific functions, such as database query capabilities (Gomis; Gall; Brahmi, 2008). And a quantitative methodology was used in articles focused on the mistakes found in generated bibliographies (see infra).

\section{Bibliography making and word proces-} sor integration were two processes that became increasingly important at the end of the 1990s

In any case, the key element of this type of study is the use of comparative function tables. Only 18 articles (48.6\%, 3 of which were quantitative comparisons, see infra) offered tables, but almost always with heterogeneous contents and organization. The use of tables became widespread in the second half of the decade of 1990, but because these studies did not use indicators of quantitative assessment, their value is limited in establishing the presence or absence of a function. These tables of presence/absence of functions are a first step to the systematic assessment of software tools, but the reviewed articles did not go any further. Another lack shown by this kind of article is that authors did not define a target group of users; therefore, they fail to establish which functions or characteristics are the most wanted and as a result they end up replicated models based on the technical features already present in the reference management software. Cibbarelli (1995) was the first to approach the question using a comprehensive survey sent to users, but the survey was focused on how users assess the reference software management tools rather than in developing a model and evaluation method to use with the collected data.

Thus, the characteristics, functions, and features offered by the reference management software tools were used to establish the assessment models used in the previously described articles. It is a model based on reviewing functions that are not ideal or based on user needs, but instead based on the existing features of the tools. The categories used and compared for analysis included data search, edition and capture, citation styles, word processor integration, data import and export, and interaction with social web services. Some studies evaluated the information on the software manufacturer and application data, as well as the required operating system. By adopting this model, these studies only confirm or deny the presence or absence of a function, without performing load tests to see if it is properly fulfilling its purpose. The only load tests documented are those corresponding to database queries and to the generation of proper reference results according to styles, which match those articles using a quantitative comparison model (see infra). The assessment criteria identified in the reviewed articles appear in table 2.

The assessment criteria identified correspond to an evaluation approach which stems from the ideal model of the desktop application, oriented towards personal work and formulated from the point of view of the expert in reference management. This has been the predominant focus in the 
field regarded as object of study: in 1988, eight attributes were established for "the perfect bibliographic software" (Brantz; Galla, 1988), whereas in 1993 a decalogue of questions was suggested to the user before they choose one or another tool (Jones, 1993). It was the common orientation until the beginning of the decade of 2010.

Regarding more specific criterias, the most common aspects are those related to capture, edition and generation of bibliographic data. In the 37 studies the authors usually focused on those same characteristics. The interest in reference annotation and pdf management capabilities began around 2010, after the function had been incorporated in reference management tools (Zotero appears in 2006). Bibliography making and word processor integration were two processes that became increasingly important at the end of the 1990s. Citation style management is another evaluation parameter that remained constant in the reviewed articles, albeit without assessing more specialized attributes such as the ability to interact with Citation style language (CSL) repositories.

The assessment of bibliographic generation capabilities and website integration made a late appearance in the articles reviewed. Not until 2002, a decade after the advent of the Web, did we find a research article (Koopman, 2002) that reviewed the quality and results of bibliographic generation. Only after the assessments incorporated for data publication and dissemination functions in social media and collaborative environments. CiteULike and Connotea were launched in 2004; Bibsonomy and Zotero in 2006. A year later, a first descriptive-comparative article was identified, including web applications with dissemination and collaborative work functions (Giménez; Tramullas, 2007). In 2006, Hendry, Jenkins, and McCarthy suggested a theoretical model to develop collaborative bibliographies, considering various collaborative work and bibliographic development and maintenance scenarios. However, the assessment of these functions kept the previous focus of enumerating and affirming or denying them, without offering measurable related criteria and data.

Although there are some basic studies on user opinion (Lo-
Table 2. Assessment criteria identified in the revised literature

\begin{tabular}{|c|c|}
\hline General criteria & Specific criteria \\
\hline Search & $\begin{array}{l}\text { External databases and other sources } \\
\text { Academic engines } \\
\text { Own/house databases }\end{array}$ \\
\hline Data capture & $\begin{array}{l}\text { Capture references from external databases } \\
\text { Manual creation of references } \\
\text { Errors in imported files }\end{array}$ \\
\hline Reference and data edition & $\begin{array}{l}\text { Edit, modify and delete references } \\
\text { Duplicate detection } \\
\text { Capacity for global data changes } \\
\text { Annotation } \\
\text { Tagging }\end{array}$ \\
\hline Bibliography creation & $\begin{array}{l}\text { Creation of bibliographical list (text format) } \\
\text { Creation of html documents } \\
\text { Errors in applying bibliographic styles }\end{array}$ \\
\hline Authorities & Creation and management of list of authorities \\
\hline Data import and export & $\begin{array}{l}\text { Import files coded in bibliographic exchange formats } \\
\text { Export files coded in bibliographic exchange formats }\end{array}$ \\
\hline File management & $\begin{array}{l}\text { Organization and management of pdf files } \\
\text { Metadata extraction of pdf files }\end{array}$ \\
\hline Bibliographic styles & $\begin{array}{l}\text { Number of available styles } \\
\text { Creation or import of new styles } \\
\text { Errors in applying styles }\end{array}$ \\
\hline Metadata & Export/import to metadata schemes \\
\hline Word processor integration & $\begin{array}{l}\text { Integration of references in word processor documents } \\
\text { Automatic generation of bibliographies in word processors }\end{array}$ \\
\hline Diffusion and publishing & $\begin{array}{l}\text { Sending references and bibliographies by email } \\
\text { Sharing references in social networks } \\
\text { RSS. }\end{array}$ \\
\hline Collaborative work & $\begin{array}{l}\text { Syncronization with bibliographic web services } \\
\text { Creation and management of shared bibliographies } \\
\text { Creation of shared work groups } \\
\text { Social tagging } \\
\text { Work offline } \\
\text { Access control }\end{array}$ \\
\hline User interface & $\begin{array}{l}\text { Customization } \\
\text { Ease of use } \\
\text { Usabilility } \\
\text { Records display options }\end{array}$ \\
\hline Reliability & Reliability \\
\hline User help & $\begin{array}{l}\text { Technical and user documentation } \\
\text { Manuals } \\
\text { Tutorials }\end{array}$ \\
\hline $\begin{array}{l}\text { Interaction with other software } \\
\text { applications }\end{array}$ & $\begin{array}{l}\text { API } \\
\text { Web version } \\
\text { Mobile version }\end{array}$ \\
\hline Seller or provider & $\begin{array}{l}\text { Product cost } \\
\text { Supported operating systems } \\
\text { Interface translations } \\
\text { User attention and support } \\
\text { License type }\end{array}$ \\
\hline
\end{tabular}

renzetti; Ghali, 2013), evaluations of usability and ease of use were not found in the reviewed articles. This provides an interesting contrast to the high number of published articles on usability in opacs and in library computerization systems.

The second most common model used by authors was a simple description, which enumerated the characteristics and features of the reference management software tools (13 articles, 35.1\%). The descriptive depth of functions and characteristics was highly heterogeneous in these articles, which means that some of them were limited to an enu- 
meration of functions without providing further verification or cross-checking. As happened with comparative descriptions, neither context of use nor a target group of users was defined. Thus, the only value of these articles is as an overview of the applications, functions, and market as they existed at a given point in time.

\section{Evaluations of usability and ease of use were not found in the reviewed articles, what contrasts with the high number of published articles on usability in opacs and in library computerization systems}

A quantitative comparison was the least common approach (5 articles, 13.5\%). Only one of the articles reviewed offered a basic quantitative approach (Basak, 2014); the other four (Garfield; Flanagan; Fox, 1989; Kessler; Van Ullen, 2005; Gilmour; Cobus-Kuo, 2011; Homol, 2014) actually conducted a quantitative assessment regarding the number of mistakes managers made when generating bibliographic references, considering various citation styles. Thus, these would be partial comparisons, exclusively based on a specific aspect of reference managers.

The review of the applied criteria in the articles revealed two distinct stages in the evolution of reference management software:

1. A first stage, up until 2006, wherein tools were understood as desktop applications, for personal purposes, with a traditional approach regarding bibliographic capture, management and generation, and therefore directed toward traditional publishing.

2. A second stage, beginning in 2007, where the emergence of web 2.0. collaboration and information dissemination through a number of web technologies was progressively incorporated.

An important aspect yet to be mentioned on this article is the support provided by librarians to their users, and as a result librarians become well-acquainted with reference management software. Recently, a handful of articles have been published that address this topic. McMinn (2011) conducted a library website review and identified 111 websites providing information about reference management software. Childress (2011) described how the library at Penn State University developed a working group to analyze patterns of reference manager utilization by its users. The analysis revealed that these tools are used within the general context of academic work including educating users about plagiarism, citation styles, and the criteria they can use to select reference management tools for their needs. More recent research by Salem and Fehrmann (2013) used focus groups to study how college students use reference management software.

\section{Conclusions}

This review of comparative studies on reference management software provides grounds to claim that there is not
The authors have compiled a list of more than a hundred references about reference management software on:

https://www.mendeley.com/groups/7448891/referencemanagement-software

https://www.zotero.org/groups/reference_management_ software

http://www.citeulike.org/group/19735

http://www.bibsonomy.org/group/biblio_software

a common or standardized method of analysis. The models applied by the authors corresponded to approaches based on their assumed expert knowledge of the tools themselves. Obviously, this approach overlooks the possibility of building ideal theoretical manager models, based on the needs and actual activities of the users. In addition, authors did not take into account the common rules and standards for software quality evaluation: they did not use inspection techniques or defined metrics, as established by the standards ISO/IEC 9126, 14598 and 25010. The current revised standard corresponds to ISO/IEC 25010 (2011), which includes the contents of the classic ISO/IEC 9126-1 (2001). A proper evaluation reference software management tools should include a quality model, characteristics, requirements, and metrics indicated in the standard. It can be stated that the reviewed articles do not show a rigorous methodology in their approach and execution of evaluations. In conclusion, the working hypothesis presented at the beginning of this article can be considered valid.

Librarians provided support to their users, and as a result they become wellacquainted with reference management software

Another observation, inferred from the review, is that there is not a standard definition or clearly described concept of "reference management software" beyond the generic claims and classic definitions. Authors of the 37 articles seemed to accept tools themselves as an ideal model and did not devote any section of their evaluation to elaborate on this concept. It should be highlighted that tools have evolved as well as the technological context. Reference management software can no longer be defined in the traditional sense provided by the reviewed literature. Currently, it is an integrated tool of information management providing support to workflows of scientific research in any given area. Fourie (2011) suggested considering reference management software as a specific type of personal information manager, with the ability to combine the information they contain with organizations and visualizations such as topic maps. Hull, Pettifer and Kell (2008) went further when reviewing the integration of digital libraries into web-based reference managers. The problems they identified to make good use of their digital content were only solved partially, through better and more powerful reference managers, and 
through information personalization and socialization.

Finally, Library science has failed to lead in this area of research and has not offered significant contributions to it, neither in theoretical nor technical aspects. The reviewed literature shows a passive attitude, merely intended as a revision, of the work of third parties. More proactive approaches did not arise until 2010. These approaches observe users and their information behavior, to plan and carry out actions with and on reference managers. As pointed out by Kern and Hensley (2011, p. 208): “...we are freed to spend less energy teaching the specifics of citation styles and more time on not only why it is essential to properly cite but to introduce more advanced information management skills..."

Library science has failed to lead in this area of research and has not offered significant contributions to it, neither in theoretical nor technical aspects

\section{References}

Bertrand, D.; Bader, C. R. (1980). "Storage and retrieval of bibliographic references using a microprocessor system". International journal of bio-medical computing, v. 11, n. 4, pp. 285-293.

http://dx.doi.org/10.1016/0020-7101(80)90033-1

Childress, Dawn (2011). "Citation tools in academic libraries". Reference \& user services quarterly, v. 51, n. 2, winter, pp. 143-152.

http://www.jstor.org/stable/refuseserq.51.2.143

Cibbarelli, Pamela (1995). “Cibbarelli's surveys: user ratings of bibliographic citation management software". Computers in libraries, n. 15, n. 4, pp. 25-40.

http://dl.acm.org/citation.cfm?id=211949\&CFID $=54147120$ 1\&CFTOKEN $=64143634$

Fourie, Ina (2011). "Personal information management (PIM), reference management and mind maps: the way to creative librarians?". Library Hi Tech, v. 29, n. 4, pp. 764-771. http://dx.doi.org/10.1108/07378831111189822

Giménez-López, Mónica; Tramullas, Jesús (2007). “Evaluación de software libre para la gestión de bibliografía". In: $1^{a}$ Jornada de software libre, IX Jornadas españolas de documentación. Santiago de Compostela.

http://hdl.handle.net/10760/11849

Hendry, David G.; Jenkins, J. R.; McCarthy, Joseph F. (2006). "Collaborative bibliography". Information processing \& management, v. 42, n. 3, pp. 805-825.

http://dx.doi.org/10.1016/j.ipm.2005.05.007

Hull, Duncan; Pettifer, Steve R.; Kell, Douglas B. (2008).

"Defrosting the digital library: bibliographic tools for the next generation web". PLoS computational biology, v. 4, n. 10, e1000204.

http://dx.doi.org/10.1371/journal.pcbi.1000204

ISO (2011). ISO/IEC 25010. Systems and software enginee- ring - Systems and software quality requirements and evaluation (SQuaRE) - System and software quality models. http://www.iso.org/iso/catalogue_detail.htm?csnumber=35733 ISO (2001). ISO/IEC 9126-1. Software engineering - Product quality.

http://www.iso.org/iso/catalogue_detail.htm?csnumber=22749

Jones, R. G. (1993). "Personal computer software for handling references from cd-rom and mainframe sources for scientific and medical reports". BMJ: British medical journal, 307, pp. 180-184.

http://www.ncbi.nlm.nih.gov/pmc/articles/PMC1678334

Kern, M. Kathleen; Hensley, Merinda K. (2011). "Citation management software: Features and futures". Reference and user services quarterly, v. 50, n. 3, pp. 204-208. http://www.citeulike.org/user/jordimgali/article/9754581

Koopman, Ann (2002). "Bibliographic citation management software for web applications". Internet reference services quarterly, v. 7, n. 1-2, pp. 99-112. http://dx.doi.org/10.1300/J136v07n01_07

Kunin, Calvin M. (1985). "Managing bibliographic citations using microcomputers". The American journal of medicine, v. 78, n. 4, pp. 627-634.

http://dx.doi.org/10.1016/0002-9343(85)90406-1

Lorenzetti, Diane L.; Ghali, William A. (2013). "Reference management software for systematic reviews and metaanalyses: an exploration of usage and usability". BMC medical research methodology, v. 13, n. 1, p. 141.

http://dx.doi.org/10.1186/1471-2288-13-141

Marino, William (2012). "Fore-cite: tactics for evaluating citation management tools". Reference services review, v. 40, n. 2, pp. 295-310.

http://dx.doi.org/10.1108/00907321211228336

McMinn, H. Stephen (2011). "Library support of bibliographic management tools: a review". Reference services review, v. 39, n. 2, pp. 278-302.

http://dx.doi.org/10.1108/00907321111135493

Moore, Carolina (1991). "Personal reference management software-how to evaluate it?". Health libraries review, v. 8, n. 1, pp. 4-10.

http://dx.doi.org/10.1046/j.1365-2532.1991.810004.x

Norman, Frank (2010). "From Sci-Mate to Mendeley - a brief history of reference managers". Trading knowledge. Blog post.

http://occamstypewriter.org/trading-knowledge/2010/06/08/ this_is_an_edited_version

Okoli, Chitu; Schabram, Kira (2010). A guide to conducting a systematic literature review of information systems research. Social Science Research Network. http://dx.doi.org/10.2139/ssrn.1954824

Salem, Jamie; Fehrmann, Paul (2013). "Bibliographic management software: A focus group study of the preferences and practices of undergraduate students". Public services quarterly, v. 9, n. 2, pp. 110-120.

$h t t p: / / d x . d o i . o r g / 10.1080 / 15228959.2013 .785878$ 


\section{Annex. Reviewed bibliography (cronologically sorted)}

Gurney, Jud W.; Wigton, Robert S. (1987). "Computerized reference management--filing the literature". American journal of roentgenology, v. 149, n. 2, pp. 411-413. http://www.ajronline.org/doi/pdf/10.2214/ajr.149.2.411

Brantz, Malcolm H.; Galla, James (1988). "Is there an optimal bibliographic software product for end users?". Bulletin of the Medical Library Association, v. 76, n. 3, pp. 216-220. http://www.ncbi.nlm.nih.gov/pmc/articles/PMC227110

Garfield, J. M.; Flanagan, H.; Fox, J. (1989). “A comparison of two microcomputer-based programs for bibliographic retrieval and formatting". Journal of clinical monitoring, v. 5, n. 3, pp. 177-185.

http://dx.doi.org/10.1007/BF01627450

Nashelsky, Joan; Earley, Dorothy (1991). "Reference management software - Selection and uses". Library software review, v. 10, n. 3, pp. 174-178.

Jones, R. G. (1993). "Personal computer software for handling references from cd- rom and mainframe sources for scientific and medical reports". BMJ: British medical journal, n. 307, pp. 180-184.

http://www.ncbi.nlm.nih.gov/pmc/articles/PMC1678334

Miller, M. C. (1994). "Reference management software: a review of EndNote Plus, Reference Manager, and Pro-Cite". M.D. computing: Computers in medical practice, v. 11, n. 3, pp. 161-168.

Cibbarelli, Pamela (1995). “Cibbarelli's surveys: user ratings of bibliographic citation management software". Computers in libraries, v. 15, pp. 25-40.

http://dl.acm.org/citation.cfm ?id=211949\& CFID $=54147120$ $1 \&$ CFTOKEN $=64143634$

Tramullas, Jesús (1995). "Investigación en sistemas bibliográficos personales: una revisión de aplicaciones freeware y shareware". In: Tendencias de investigación en documentación. Actas del seminario. Zaragoza: Universidad de Zaragoza, pp. 51-73.

Bravo-Toledo, Rafael (1996). "Gestores personales de bases de datos bibliográficas". El profesional de la información, n. 48 (October).

http://www.elprofesionaldelainformacion.com/contenidos/1996/ octubre/gestores_personales_de_bases_de_datos_bibliogrficas. html

Nicoll, Leslie H.; Ouellette, Teena H.; Bird, Donna C.; Harper, Jane; Kelley, Janice (1996). "Bibliography database managers. A comparative review". Computers in nursing, v. 14, n. 1, pp. 45-56.

http://www.nursingcenter.com/journalarticle?Article_ ID $=433547$

Bravo-Toledo, Rafael; Astorga-Díaz, Pablo (2000). “Cómo gestionar nuestra bibliografía: creación y mantenimiento de un archivo bibliográfico personal". Atención primaria, v. 25, n. 6, pp. 134-140.

http://www.elsevier.es/es-revista-atencion-primaria-27articulo-como-gestionar-nuestra-bibliografia-creacion-11169
Shapland, Maggie (2000). "Evaluation of reference management software". London: South Bank University, Library and information briefings, vols. 89/90, 30 pp.

Koopman, Ann (2002). "Bibliographic citation management software for web applications". Internet reference services quarterly, v. 7, n. 1-2, pp. 99-112. http://dx.doi.org/10.1300/J136v07n01_07

May, Mike (2003). "Sorting out citation management software". The scientist, v. 17, n. 20, pp. 37-39.

http://www.the-scientist.com/?articles.view/articleNo/15165/ title/Sorting-Out-Citation-Management-Software

Kessler, Jane; Van Ullen, Mary K. (2005). "Citation generators: Generating bibliographies for the next generation". The journal of academic librarianship, v. 31, n. 4, pp. 310-316. http://dx.doi.org/10.1016/j.acalib.2005.04.012

Mattison, David (2005). "Bibliographic research tools round-up". Searcher: Magazine for database professionals, v. 13, n. 9, pp.16-27.

http://connection.ebscohost.com/c/articles/18438501/ bibliographic-research-tools-round-up

Duarte-García, Emilio (2007). “Gestores personales de bases de datos de referencias bibliográficas: características y estudio comparativo". El profesional de la información, v. 16, n. 6, pp. 647-656.

http://dx.doi.org/10.3145/epi.2007.nov.12

Smith, Cheryl M.; Baker, Bradford (2007). "Technology in nursing scholarship: use of citation reference managers". International journal of mental health nursing, v. 16, n. 3, pp. 156-60. http://dx.doi.org/10.1111/j.1447-0349.2007.00462.x

Giménez-López, Mónica; Tramullas, Jesús (2007). “Evaluación de software libre para la gestión de bibliografía". In: Fesabid (ed.), IX Jornadas españolas de documentación. Santiago de Compostela.

http://hdl.handle.net/10760/11849

Hernández, David A.; El-Masri, Maher M.; Hernández, Cheri-Ann (2008). "Choosing and using citation and bibliographic database software (BDS)". The diabetes educator, v. 34, n. 3, pp. 457-74.

http://dx.doi.org/10.1177/0145721708317875

Gomis, Melissa; Gall, Carole; Brahmi, Frances A. (2008). "Web-based citation management compared to EndNote: options for medical sciences". Medical reference services quarterly, v. 27, n. 3, pp. 260-71.

http://dx.doi.org/10.1080/02763860802198804

Cordón-García, José A.; Martín-Rodero, Helena; AlonsoArévalo, Julio (2009). "Gestores de referencias de última generación: análisis comparativo de RefWorks, EndNote Web y Zotero". El profesional de la información, v. 18, n. 4, pp. 445-454.

http://dx.doi.org/10.3145/epi.2009.jul.14

Butros, Amy; Taylor, Sally (2010). "Managing information: evaluating and selecting citation management software, a look at EndNote, RefWorks, Mendeley and Zotero". In: Netting knowledge: two hemispheres/one world: Procs of the $36^{\text {th }}$ lamslic annual conf, pp. 1-47. 
http://darchive.mbl.edu/bitstream/handle/1912/4595/ Butros-Taylor_iamslic2010.pdf?sequence $=1$

Fenner, Martin (2010). "Reference manager overview". Gobbledygook PLoS blogs.

http://blogs.plos.org/mfenner/reference-manager-overview

Alonso-Arévalo, Julio (2010). "Gestores de referencias sociales: la información científica en el entorno 2.0". In: Anuario ThinkEPI. Barcelona: EPI SCP.

http://recyt.fecyt.es/index.php/ThinkEPI/article/view/31277

Gilmour, Ron; Cobus-Kuo, Laura (2011). "Reference management software: A comparative analysis of four products". Issues in science and technology librarianship, n. 66, Summer. http://dx.doi.org/10.5062/F4Z60KZF

Kern, M. Kathleen; Hensley, Merinda K. (2011). “Citation management software: Features and futures". Reference and user services quarterly, v. 50, n. 3, pp. 204-208.

http://www.citeulike.org/user/jordimgali/article/9754581

Rapp, David (2011). “Reference management tools". Library journal, n. 136, pp. 38-38.

http://lj.libraryjournal.com/2011/11/lj-in-print/productwatch-reference-management-tools

Web, W.; Platter, S. (2011). "Reference management software". Ukolug newsletter eLucidate.

Glassman, Nancy R.; Sorensen, Karen (2012). "Citation management". Journal of electronic resources in medical libraries, v. 9, n. 3, pp. 223-231.

http://dx.doi.org/10.1080/15424065.2012.707097

Zhang, Yingting (2012). "Comparison of select reference management tools". Medical reference services quarterly, v. 31, n. 1, pp. 45-60.

http://dx.doi.org/10.1080/02763869.2012.641841
Mahajan, Amit K.; Hogarth, D. Kyle (2013). "Taking control of your digital library: how modern citation managers do more than just referencing". Chest, v. 144, n. 6, pp. 19301933.

http://dx.doi.org/10.1378/chest.13-0856

Steeleworthy, Michael; Dewan, Pauline (2013). "Webbased citation management systems: Which one is best?" Partnership: The Canadian journal of library and information practice and research, v. 8, n. 1, pp. 1-8.

https://journal.lib.uoguelph.ca/index.php/perj/article/ view/2220/2781

Homol, Lindley (2014). "Web-based citation management tools: Comparing the accuracy of their electronic journal citations". The journal of academic librarianship, v. 40, n. 6 , pp. 552-557.

http://dx.doi.org/10.1016/j.acalib.2014.09.011

Casado-Pardo, Joaquín; Maroto-Martín, Salvador; Dani, Lubna; Ávila-de-Tomás, José F. (2014). "Gestores bibliográficos". FMC - Formación médica continuada en atención primaria, v. 21, n. 6, pp. 355-359.

http://dx.doi.org/10.1016/S1134-2072(14)70786-8

Yamakawa, Eduardo-Kazumi; Kubota, Flávio-Issao; Beuren, Fernanda Hansch; Scalvenzi, Lisiane; Miguel, Paulo-Augusto-Cauchick (2014). "Comparativo dos softwares de gerenciamento de referências bibliográficas: Mendeley, EndNote e Zotero". Transinformação, v. 26, n. 2, pp. 167-176. http://dx.doi.org/10.1590/0103-37862014000200006

Basak, Sujit Kumar (2014). “A comparison of researcher's reference management software: Refworks, Mendeley, and EndNote". Journal of economics \& behavioral studies, v. 6, n. 7, pp. 561-568.

http://www.ifrnd.org/Research\%20Papers/J6\%287\%295.pdf

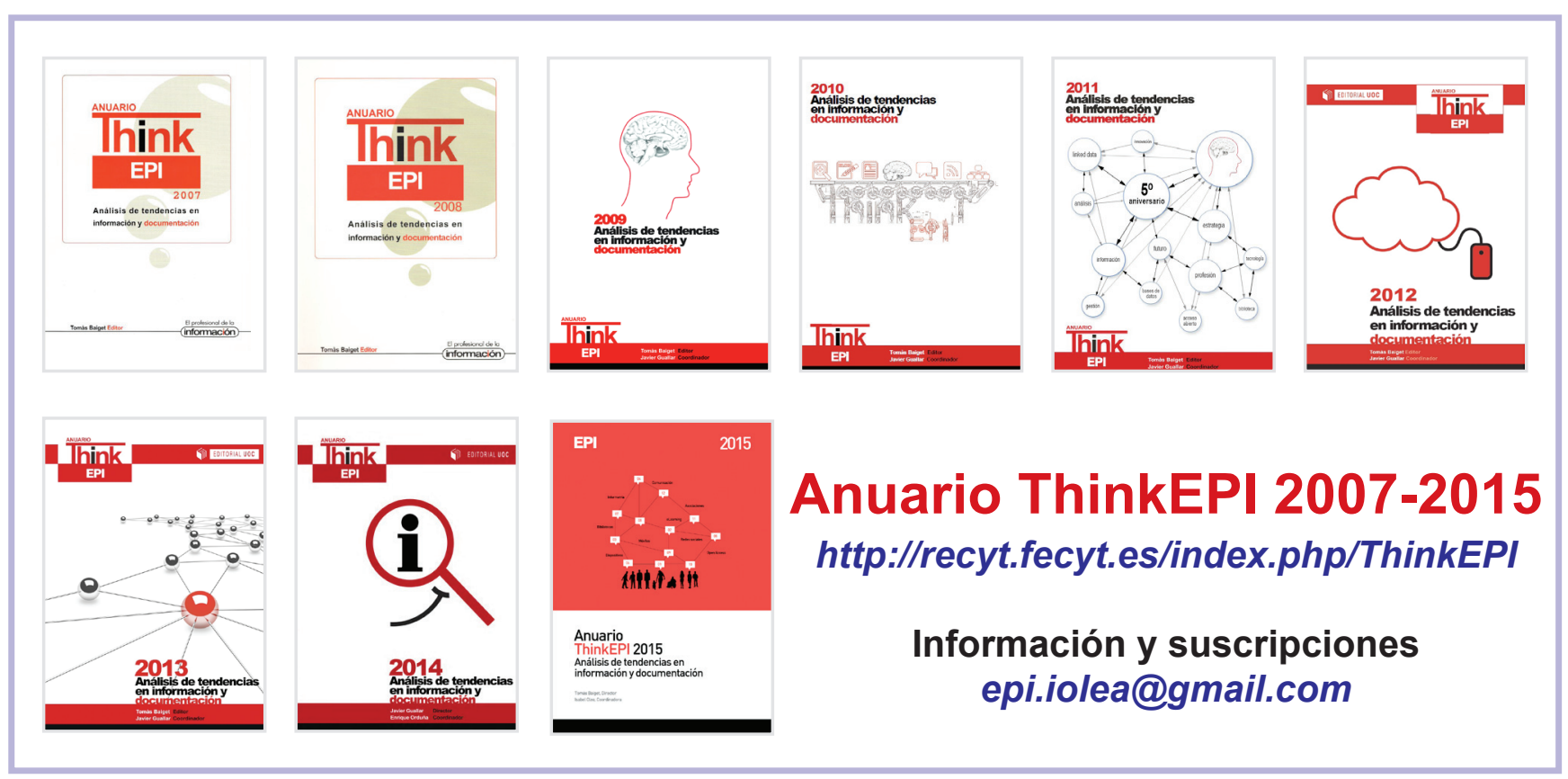

